\title{
The Marlboro Man on coral beaches
}

Testing of French nuclear weapons has recently led to increasing resentment against the use of tranquil Pacific islands for the detonation of nuclear weapons. Chapman has pointed out the much greater threat to the Pacific that comes from the cancer colonisation of tobacco in the region. ${ }^{1}$ Tobacco use in the Pacific has risen alarmingly.

The photograph on the cover of this issue of Tobacco Control was taken in the Pacific island country of Vanuatu, in a village near the town of Loganville (population more than 7000), on the island of Espiritu Santo. Vanuatu is a "Y"-shaped archipeligo of some 80 islands, with about 68 being inhabited. The land area is $12200 \mathrm{~km}^{2}$ with an estimated population of 155800 on 11 main groups of islands. In 1989 the census indicated 1708 villages, with $80 \%$ living in localities with fewer than 50 people. There is a very high population growth rate, close to $3 \%$ a year, and both the infant mortality rate and the death rate have been falling over the last decades.

The cover photo was taken in one of these villages, a "cameo" picture of what is happening in the Pacific. The village boy is holding a Marlboro pack, bought at low cost and advertised widely throughout the region. The picture was taken by Peter Truscott, a project supervisor for the Adventist Development and Relief Agency, while visiting Vanuatu to supervise a children's literacy programme. The picture features a ni-Vanuatu (traditional Vanuatu) boy in one of these rural villages holding in his hand the symbol of Western influence. Although food is generally not in short supply, about a third of children in the northern area of Vanuatu are underweight and there are obvious signs of malnutrition in the distended abdomen of this boy. It is an indictment of Western influence that, where malnutrition abounds, the Marlboro man is making inroads with increased sales.

The World Bank recently highlighted the health needs within the Pacific in a report, Health priorities and options in the World Bank's Pacific member countries. ${ }^{2}$ The report states that in Vanuatu, "smoking is now very common and while there has been growth of tobacco imports, much smoking is [of] home grown/traditional products. A 1985 survey indicates that between 54 and 80 percent of men smoke tobacco, with the higher rates in rural areas."

A review of smoking rates in the Pacific indicates that prevalence among many of the Pacific islands is as high as anywhere in the

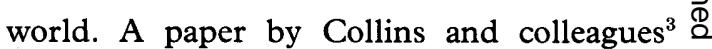
shows levels of smoking up to $90 \%$ in some communities. Earlier work of Tuohlimehto $\overrightarrow{0}$ had indicated a high prevalence of smoking in the Pacific. ${ }^{4}$ Tobacco Control published a report $\vec{\omega}$ by Woodward showing that smoking prevalence in Tonga was $65 \%$ for men and $14 \%$ for $v$ women. ${ }^{5}$ The islands of Tokelau were earlier $\vec{\sim}$ studied by Wessen, with smoking prevalence 0 in men as high as $76 \%$ and in women at certain ages reaching $70 \%$. The smoking prevalence $z$ among some Micronesian students is $39 \%$ for males and $32 \%$ for females, with age of uptake $\stackrel{\circ}{\supset}$ as young as 6 years. ${ }^{6}$

Many of the Pacific countries are poor, with $\mathscr{\&}$ dependence on overseas aid, and yet facing the prospect of forest exploitation, rise of sea levels due to global warming, and changes in the patterns of fishing from the entrance of international fleets.

Smoking rates in the Pacific seem unlikely to change in the near future for several reasons. $\frac{\mathrm{O}}{3}$ Governments are generally not willing to put the necessary energy into effective legislation. The tobacco issue is certainly not given priority and funding from regional health agencies. There is little or no effort in some countries to educate the population or raise the tax on tobacco and make it a less attractive consumer item.

In addition, the tobacco industry plays the trump cards of sport and business in these countries so dependent on external aid. The $\delta$ Pacific islands present a "cameo" of much of $₹$ Asia, but without the economic advancement 을 of Asia.

Tobacco control advocates must continue their work for the children of the world, O represented by the ni-Vanuatuan boy shown on the cover. The global tobacco industry has concealed information on the addictive, damaging nature of their product, which produces cancer and significantly impacts the health of $\stackrel{\varrho}{\bar{C}}$ non-smokers by exposure to environmental $\stackrel{\mathbb{S}}{\rightarrow}$ tobacco smoke. ${ }^{7}$ Even the more basic infor- 0 mation on damage to health from smoking is often not known in the Pacific. Politicians and $\stackrel{\triangle}{\curvearrowright}$ decision makers in the Pacific must take the $\mathbb{D}$ necessary steps to legislate and regulate the $\overline{0}$ "lethal trade".

What type of lifestyles will be seen among Pacific children in the future? Will the first impressions be that of the colonial tobacco "cowboy", a Western destructive lifestyle, or a lifestyle that offers something more than the false promises and illusions of "Marlboros Come to where the flavour is"? Pacific coun-
148 Fox Valley Road
Wahroonga, 2076, Australia Harley J Stanton 
tries need strong legislative tobacco control initiatives now if they are to halt the "cloud of doom" already hanging over the region and to progress health improvements.

1 Chapman S. Cancer colonialism begins at home. The Bulletin (Australian Consolidated Press, Sydney), 1995 Aug 22: 52.

2 World Bank. Health priorities and options in the World Bank's Pacific member countries. Population and Human Resources Division, Aug 1994.

3 Collins VR, Dowse GK, Zimmet PZ. Prevalence and trends in smoking in Pacific Island populations. Pacific Health Dialog 1996; 3: (in press).

4 Tuomilehto J, Zimmet P, Taylor R, Bennet P, Wolf E, Kankaanpaa J. Smoking rate in Pacific Islands. Bull WHO 1986; 64: 447-56.
5 Woodward A, Newland H, Kinahoi M. Smoking in the Kingdom of Tonga: report from a national survey. Tobacco Control 1994; $1: 41-5$.

6 Durand AM. Sexual behaviour and substance abuse among students in CNMI. Pacific Health Dialog 1995; 2: 24-30.

7 Glantz SA, Barnes DE, Bero L, Hanauer P, Slade J. Looking through a keyhole at the tobacco industry: the Brown and Williamson documents. $f A M A 1995 ; 274$ : 219-24.

The author is chairman of the Tobacco and Cancer Program of the International Union Against Cancer, Asia South-Western Pacific Region; and Associate Director of the Adventist Health Department, South Pacific Division.

$$
\text { - ED }
$$

\section{Note to readers}

We hereby solicit your ideas and contributions for future covers of Tobacco Control. As with previous covers, we would like future covers to be colourful and creative - with a tobacco control theme. Original artwork, anti-tobacco posters, photographs, and cartoons may all be considered. Material with an international flavour would be particularly desirable. A cover essay will generally appear in each issue to provide appropriate background information and commentary on the cover.

Please send ideas and submissions (original or high-quality, camera-ready photographs) to the editor at the address on the inside front cover. - ED

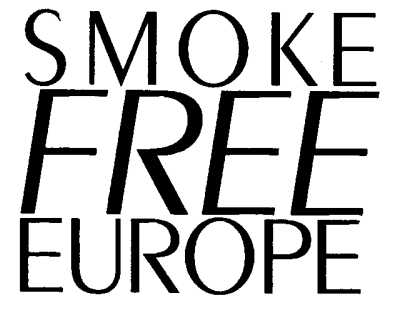
CONFERENCE ON TOBACCO OR HEALTH

\section{Helsinki, Finland • October 2-4, 1996}

The European Tobacco Conference on Smoking or Health is an open forum for all those interested in the tobaccorelated issues. There is a need for coordinated action in Europe right now. Participation fee for three days is FIM 1600. Early registration and abstract deadline 10 June 1996.

President of the Conference is dr. Liisa Elovainio, Cancer Society of Finland. Chairman of the Organizing Committee is professor Pekka Puska, National Public Health Institute, Finland.

Organized by Finnish Centre for Health Education and Ministry of Social Affairs and Health.

Supporters include Europe against Cancer-programme.

Finnish Centre for Health Education • Karjalankatu 2 C 63, FIN-00520 Helsinki • Tel.+358 0 148 46। I, Fax. $+35801485919 \bullet$ www-address: http://www.uicc.ch/events/helsinki 